\title{
Resistant starch: an indigestible fraction of foods.
}

\author{
Por F. Saura Calixto* and R. Abia. \\ Instituto de Nutrición y Bromatología (CSIC-UCM) \\ Facultad de Farmacia. Ciudad Universitaria \\ 28040 - Madrid (España)
}

\section{RESUMEN}

Almidón resistente: una fracción indigestible en los alimentos.

El almidón resistente (RS), fracción de almidón de la dieta que no es digerido en el intestino delgado, puede alcanzar hasta un $20 \%$ del almidón en productos derivados de cereales y legumbres.

Varias fracciones contribuyen al contenido total de almidón resistente: amilosa retrogradada, almidón inaccesible físicamente a los enzimas digestivos, almidón indigestible debido a inhibición de $\alpha$-amilasas y almidón complejado con otros constituyentes de los alimentos.

El almidón resistente se forma en productos que han sufrido tratamientos térmicos (panificación, extrusión, autoclave, etc.)

El RS aumenta el volumen de heces y es fermentado parcialmente en el colon por bacterias anaeróbicas. Igualmente, está relacionado con los niveles de glucosa en sangre y la respuesta de insulina en humanos.

Se describen los métodos analíticos para su determinación.

PALABRAS-CLAVE: Almidón resistente - Análisis - Formación - Información (articulo) - Propiedades.

\section{SUMMARY}

Resistant starch: an indigestible fraction of foods.

Resistant starch (RS), the dietary starch that scape digestion in the small intestine, can yields up to $20 \%$ of the starch in cereal and legume products.

Several fractions contribute to the total RS of foods: retrograded amylose, starch inaccessible to digestive enzymes because of mechanical barriers, chemically modified starch fragments, undigested starch due to $\alpha$-amylase inhibitors and starch complexed with other food components.

RS is formed in products processed following heat treatments (baking, extrusion, autoclaving, etc.).

RS produces significant faecal bulking and is partially fermentable by anaerobic bacteria of the colon. On the other hand, the relation of resistant starch with the glucose and insulin response in human subjects is an important nutritional effect.

RS analytical methods are reported.

KEY-WORDS: Analysis - Formation - Information (paper) Properties - Resistant starch.

\section{1.-INTRODUCTION}

Starch is the most important carbohydrate source in human nutrition. This $\alpha$-glucan is a composite of amylose and amylopectin.

Amylose has a linear structure with 1,4 glycosidic bounds, whereas in amylopectin the structure in branched with $\alpha-1,4$ and $\alpha-1,6$ glycosidic bounds. The proportion of the two constituents vary according to the source, but amylose constituent is usually the minor component $(15-30 \%)$ of the total glycan. The molar masses amount to about 150.000 to 750.000 for amylose, whereas it amounts up to 10 millions for amylopectin.

Amylose may be found in various crystalline polymorphous with right-handed double helices and left-handed single helices. Amylopectin is a branched polydisperse polymer with an amylose type 1-4 $\alpha$ linked backbone that bears clusters of 1-6 $\alpha$ linked glucopyranosyl branched with average length of 20-30 residues (1).

The starch is broken down and absorbed in the human digestive tract, providing energy. Thus, the starch content included in tables of composition of foods is considered completely digestible (2) and the energy intake in Kcal is estimated as "g starch $\times 4.1$ ".

However, recent studies have shown that an important fraction of starch may escape to the action of the digestive enzymes, increasing the amount of indigestible matter vegetable of foods (3) (4) (5) and lowering the energy value of complex carbohydrates (6). This starch fraction is the focus of the present article.

\section{2.-RESISTANT STARCH: CONCEPT}

The long-held opinion that starch is readily digested and absorbed in the small intestine has been 
challenged. Thus, there are several reports of starch been malabsorbed from ordinary foods. Up to $20 \%$ of the starch in white bread, pasta, beans and potatoes, seem to pass undigested through the colon in healthy subjects where it is fermented (7) (8) (9) (10).

There are several factors affecting the degradation of starch in foods (11). Raw starch granules are very slowly digested by enzymes. However the structural, physical and chemical properties of starch are more or less modified during cooking and processing, and this affect the susceptibility of starch to enzymes action. During processing the addition of heat, elevated pressures and mechanical stresses affect starch availability to different extent. Gelatinization and disruption of the compact granular structure and starch retrogradation are the main factors related with enzyme degradation (12).

Resistant starch (RS) has been recently defined (13) as dietary starch that escape digestion in the small intestine. Several starch fractions can contribute to the total RS of foods:

a) Retrograded starch ( $R e S$ ). Starch that has crystallized after gelatinization.

It is a short-chain $\alpha$-glucan, essentially linear. There is a direct association between amylose content and yield of $R e S$, but debranching or linearization of amylopectins is sufficient to generate $R e S$ (14).

$\operatorname{Re} S$ is a product of spontaneous changes occurring on subsequent cooling, ageing and drying of gelatinized starch (15). It is a characteristics fraction formed in baking. The baking condition may increase the $\mathrm{Re} S$ of the flour producing breads with significant amounts of R $S(16)$.

$\operatorname{Re} S$ is solubilized with solvents able to break the hydrogen bonds formed during retrogradation $(2 \mathrm{M} \mathrm{KOH}$ or Dimethylsulphoxide), becoming after solubilitation available to enzymatic hydrolysis.

b) Indigestible starch because of mechanical barriers in the food matrix.

This type of starch is found in raw foods or in food that have been cooked or processed without a previous complete milling. It is the case of raw potato and banana or in partially milled cereals and legumes. Starch is not accessible to the digestive enzymes because it is enclosed within granules in the plant tissue (4) (17).

c) Chemically modified starch fragments.

Starch modified by heat treatments, specially at low moisture. 1,6 Anhydro B-D glucopyranose and oligosaccharides with this units are formed and this highly reactive compounds is active in transglycositation reactions. The modifications reduce the digestibility of starch (18) (19). d) Undigested starch due to the action of $\alpha$ amylase inhibitors and antinutrients.

The presence of phytic acid (20), polyphenols (21), condensed tannis (22), may inhibit $\alpha$-amylases and subsequently the degradation and digestion of starch.

e) Starch complexes with other food components.

Starch may form indigestible complexes by interaction with protein, lignin, cellulose, oil, pectins, etc. During processing of food, especially at high temperature, increase the amount of resistant starch. This artifacts could be insoluble in $2 \mathrm{M} \mathrm{KOH}$ or dimethylsulfoxide. Very few studies in this topic have been carried out (23).

Preliminary results suggest the possible formation of indigestible amylose-casein complexes by heat treatments (24).

\section{3.-RESISTANT STARCH AND NUTRITION}

The presence of RS in starchy foods decrease the potential availble carbohydrate and energy expected from their chemical composition.

Resistant starch survives the action of endogenous mammalian enzymes to reach the large bowel, and was recovered from faeces of both human volunteers and mice (10). RS produces significant faecal bulking and is at least partially fermentable by anaerobic bacteria of the colon, in common with many of the components of dietary fibre (25).

Incomplete starch digestion could contribute to the growth of colon microorganisms. It has been suggested that the high faecal bulking capacity of the traditional African diet is related, not only to the dietary fibre content but to incomplete digestion and absorbtion of starch (26).

The glucose and insulin response in human subjects is strongly related to the rate of starch hydrolysis. However, ather factors such as rate of gastric emptying may be important.

The application of resistant starch containing foods in clinical nutrition for diabetics is promising (27) (28).

It has been suggested that the delivery of starch to the colon may help to protect against colonic carcinogenesis. It was observed that healthy subjects malabsorbed twice as much potato starch as did patient with a history of adenoma (10).

The reduction of digestibility of starch may be of negative nutritional consequence if $R S$ is used for incorporation into baby foods. However, in adults, an increase in unabsorbed starch may be in fact nutritionally advantageous by increasing faecal bulk and providing the faecal flora with a readily available source of carbohydrates (29). 


\section{4.-RESISTANT STARCH FORMATION}

RS is formed in some cooked foods and in products processed following heat treatments, such as baking, autoclaving and extrusion (10) (16) (26) (30) (31) (32) (33).

The dietary fibre content in white wheat bread was almost $20 \%$ higher than in the corresponding flour. The increment was explained by the formation of resistant starch.

Yields of $9 \% \mathrm{RS}$ in wheat starch at autoclaving at $134^{\circ} \mathrm{C}\left(2,5 \%\right.$ at $\left.100^{\circ} \mathrm{C}\right)$ with excess water were found after cooling and higher levels still (15\%) after five repeated cycles of autoclaving and cooling.

Several factors influence the yield of resistant starch during heat treatments: amylose content, processing temperature and time, water content, extent of starch gelatinization, $\mathrm{pH}$, amylose/amylopectin ratio number of heating-cooling cycles, freezing and drying (34).

Two different pathways of RS formation by heat treatments were reported: at high and at low moisture.

At high moisture, swelling and gelatinization of starch granules will occur and the degree of gelatinization depend on the temperature and amount of water; the amorphous network upon cooling retrograde and became more crystalline (3) (23) (26) (35).

Processing at limited water content may result in fragmentation and chemical modification of starch. Starch fragments with 1,6 anhydro B-glucopiranose end groups is occurring. Heat treatments reduce starch availability (18).

On the other hand, the heat treatments induce new non-starch linkages which reduce the availability to amylolitic cleavage in vitro. This new linkages reduce the availability similarly as introduction of hydroxipropyl groups in the commercial chemically modified starches (36).

Modification of the physiological properties of starch by processing creates new opportunities for production of foods with special properties.

\section{5.-RESISTANT STARCH ANALYSIS}

The first step in determination of resistant starch in foods is the removal of the digestible starch.

Previous oil extraction and protein degradation in the samples is also convenient because of enzymatic availability of starch may be reduced by formation of starch lipids and starch protein interactions (37).

Oil, protein and digestible starch, are removed in vegetables to determine dietary fibre. Heat stable amylase, protease and amyloglucosidase incubation are used in the present dietary fibre methods (38) (39). Subsequently, the corresponding dietary fibre residues are suitable samples to determine RS.

RS is solubilized with $2 \mathrm{M} \mathrm{KOH}$ or alternatively with dimethylsulfoxide. Both compounds solubilize retrograded starch by disrupting the hydrogen bounds of the crystallin structures (40) (41) (42).

One of the most widely used method to determinate RS is described by Siljestrom and Asp (16):

The amount of starch remaining in the fibre residue obtained with the AOAC enzymatic gravimetric method $(38)$ is determined by suspending the residue (10 $\mathrm{mg}$ ) in distilled water $(1 \mathrm{ml})$ and heated for $15 \mathrm{~min}$ in a boiling water bath.

$4 \mathrm{M} \mathrm{KOH}(1 \mathrm{ml})$ is added being the residue solubilizated at room temperature for $30 \mathrm{~min}$ and then neutralizated with $2 \mathrm{M} \mathrm{HCl}(4 \mathrm{ml})$ and incubated with amyloglucosidase $\left(10 \mu \mathrm{l} ; 30 \mathrm{~min} / 60^{\circ} \mathrm{C}\right)$.

Released glucose is then determinate with Glucose-oxidase-peroxidase reagent.

Starch content is expressed as polymer weight (0.9 $x$ monomer weight).

The results correspond to the $a, b, d$ and e resistant starch fractions described above (RS concept section). Nevertheless, the chemically modified fractions (and in some cases the fraction b) produced in foods treated at high temperature and low moisture are not analyzed using this method. HPLC is used to determine 1,6 anhydro B-D glucopyranose and oligosaccharides on $80 \%$ ethanol solutions corresponding to the previous dietary fibre analysis (18).

Further research is needed to develop methodology to analyze the interaction between starch and other food constituents or by chemical modifications which may be insoluble in $2 \mathrm{M} \mathrm{KOH}$.

Amylose bind $19.5 \% \mathrm{w} / \mathrm{w}$ of iodine and amylopectin $0.5 \% \mathrm{w} / \mathrm{w}$ iodine under standard conditions. The $\lambda \max$ of the high molecular weigh amylose iodine complex occurred at $642 \mathrm{~nm}$. The degree of polymerization of $R S$ can be deduced from $\lambda$ max of iodine bounded samples (34) (36).

The degree of branching in RS is estimated by digestion with pullulanase, because this enzyme is specific to hydrolize $\alpha-1,6$ linkages (30).

$X$-ray diffraction and differential scanning calorimetry are complementary used to study the crystalline structure of RS, and to distinguish between the two starch components, because recrystallized amylopectin has a melting point of about $60^{\circ} \mathrm{C}$, while amylose is above $100^{\circ} \mathrm{C}(36)$. 


\section{BIBLIOGRAPHY}

1 Yalpani, M.-"Polysaccharides: Syntheses, Modifications and Structure", p 11.-M. Yalpani (Ed), Elsevier, Amsterdam, 1988.

2. Gray, G.M. and Fogel, M.R.-"Nutritional aspects of dietary carbohydrates" in "Modern nutrition in health and disease".-Goddard, R.S. and Shils, M.E. (Ed), Lea and Febiser. Philadelphia, 1980.

3. Holm, J.; Asp, N.G., and Björck, I.-"Factors affecting enzymatic degradation of cereal starches in vitro and in vivo" in "Cereals in a European contex", p 169.-I.D. Morton (Ed), Ellis Horwood Ltd., Chichester, England and VCH, Weinheim, FRG., 1987.

4. Wursch, P.; Delvedovo, S., and Koellreutter, B.-“Cell structure and starch nature as key determinants of the digestion rate of starch in legume".-Am. J. Clin. Nutr. 43 (1986) 25-29.

5. François, P.L.-"In vitro availability of starch in cereal products". J. Sci. Food Agric. 49 (1989) 499-501.

6. The British Nutrition Foundation.-"Complex carbohydrates in foods".-Chapman and Hall, London, 1990.

7. Stephen, A.M.; Haddal, A.C., and Levitt, M.D.-"Passage of carbohydrate into the colon".-Gastroenterology 85 (1983) 589-595

8. Andersson, I.H.; Levine, A.S., and Levitt, M.D.-"Incomplete absorption of the carbohydrate in all-purpose wheat flour".-N. Engl. J. Med. 304 (1981) 891-892.

9. Wolf, M.J.; Knoo, V., and Inglett, G.E.-“Partial digestibility of cooked amylomaize starch in human and mice".-Starch 29 (1977) 401-436.

10. Björck, I.; Nyman, M.; Pederson, P.; Siljestrom, M.; Asp, N.G. and Eggum, B.O.-"Formation of enzyme resistant starch during autoclaving of wheat starch: Studies in vitro and in vivo".-J. Cereal Sci. 6 (1987) 159-172.

11. Snow, P., and O'Dea, K.-"Factors affecting the rate of hydrolysis of starch in food".-Am. J. Clin. Nutr. 34 (1981) 2721-2727.

12. Hellendoorn, E.V.-“Aspects of retrogradation in some dehydrated starch containing precooked food products".-Starch 23 (1971) 63-67.

13. Euresta-Meeting. European Flair concerted action on Resistant Starch. Wageningen Agricultural University. Department of Human Nutrition. Wageningen. The Netherlands, 1990.

14. Miles, M.V.; Morris, V.J., and Ring, S.G.-"Gelation of amylose".-Carbohydrate Res. 135 (1985) 257-269.

15. Roulet, P.; Mac Innes, W.M.; Gumy, D., and Würsch, P.-"Retrogradation kinetics of eight starches".-Starch 42 (1990) 99-101.

16. Siljestrom, M., and Asp, N.G.-"Resistant starch formation during baking. Effect of baking time and temperature and variations in the recipe".-Z. Lebensm. Unters. Forsch. 181 (1985) 4-8.

17. Englyst, H.N., and Cummings, J.H.-"Digestion of polysaccharides of potato in the small intestine of man".-Am. J. Clin. Nutr. 45 (1987) 423-431.

18. Theander, O., and Westerlund, E.-"Studies on chemical modifications in heat-processed starch and wheat flour".-Starch 39 (1987) 88-93.

19. Siljestrom, M.; Björck, I., and Westerlund, E.-“Transglycosidation reactions following heat treatment of starch effects in enzymatic digestibility".-Starch 41 (1989) 95-100.

20. Bjöck, I., and Nyman, M.-"In vitro effects of phytic acid and polyphenols on starch digestion and fiber degradation". $\checkmark$. Food Sci. 52 (1987) 1588-1594.

21. Griffiths, D.W., and Moseley, G.-"The effects of diets containing field beans of high or low polyphenolic content on the activity of digestive enzymes in the intestine of rats".J. Sci. Food Agric. 31 (1980) 255-259.

22. Horigome, T.; Kumar, R., and Okameto, K.-"Effects of condensed tannins prepared from leaves of fodder plants on digestive enzymes in vitro in the intestine of rats".-Br. J. Nutr. 60 (1988) 275-285.
23. Carrillo, P.J.; Gilbert, S.G., and Daun, H.-"Starch solute interaction in water sorption as affected by pretreatment". J. Food Sci. 53 (1988) 1199-1203.

24. Saura Calixto, F., and Abia, R.-Instituto de Nutrición y Bromatologia, Madrid, (unpublished data).

25. Nyman, M.; Björck, I.; Hakansson, B., and Asp, N.G.-“Popping of whole grain wheat: Effects on dietary fibre degradation in the rat intestinal tract".-J. Cereal Sci. 5 (1987) 67-72.

26. Björck, I.; Nyman, M.; Pedersen, B.; Siljestrom, M.; Asp, N.G., and Eggum, B.O.-"On the digestivility of starch in white bread. Studies in vitro and in vivo".J. Cereal Sci. 4 (1986) 1-11.

27. Behall, K.M.; Scholfield, D.J., and Canany, J.-"Effect of starch structure on glucose and insulin response in adults".-Am. J. Clin. Nutr. 47 (1988) 428-432.

28. Goddard, M.S.; Young, G., and Marcus, R.-"The effect of amylose content on insulin and glucose response to ingested rice".-Am. J. Clin. Nutr. 39 (1984) 388-392.

29. Sthetty, P.A., and Kurpad, A.V.-"Increasing starch intake in the human diet increases fecal bulking".-Am. J. Clin. Nutr. 43 (1986) 210-212.

30. Davidson, V.J.; Paton, D.; Dilsady, L.L., and Larucque G.-"Degradation of wheat starch in a single screw extruder: characteristics of extruded starch polymers". J. Food Sci. 49 (1984) 453-458.

31. Gomez, M.H.; Waniska, R.D.; Rooney, L.W., and Lusas, E.W.-"Extrusion-cooking of sorghum containing different amounts of amylose".-J. Food Sci. 53 (1988) 1818-1822.

32. Ostergard, K.; Björck, I., and Vainionpaa, J.-“Effects of extrusion cooking on starch and dietary fibre in barley".-Food Chem. 34 (1989) 215-227.

33. Gujska, E., and Khan, K.-“Effect of temperature on properties of extrudates from high starch fractions of navy, pints and garbanzo beans".-J. Food Sci. 55 (1990) 466-469.

34. Ring, S.G.; Gee, J.M.; Whittam, M.; Orford, P., and Johnson, I.-"Resistant starch. Its chemical form in food stuffs and effects on digestibility in vitro".-Food Chem. 28 (1988) 97-109.

35. Miles, M.J.; Morris, V.C.; Orford, P.D., and Ring, S.G.-"The roles of amylose and amylopectin in the gelation and retrogradation of starch".-Carbohydrate Res. 135 (1985) 271-281.

36. Siljestrom, M.; Eliasson, A.C., and Björck, I.-"Characterisation of resistant starch from autoclaved wheat starch".-Starch 41 (1989) 147-151

37. Holm, J.; Björck, I.; Asp, N.G.; Sjoberg, L.B., and Lundquist, I.-"Starch availavility in vitro and in vivo after flaking, steamcooking and popping of wheat".J. Cereal Sci. 3 (1985) 193-206.

38. Prosky, L.; Scheweizer, T.F.; De Vries, J.W., and Furda, 1.-"Determination of insoluble, soluble and total dietary fiber in foods and foods products: Interlaboratory study".-J. Assoc. Off. Anal. Chem. 71 (1988) 1017-1023.

39. Scheweizer, T.F.-“Dietary fiber analysis”--Lebensm. Wiss. Technol. 22 (1989) 54-59.

40. Brown, G.A., and Volenec, J.-"Isolation and molecular composition of starch from roots of Medicago Sativa L".-Starch 41 (1989) 247-250

41. Englyst, H.N., and Cummings, J.H.-"Simplified method for the measurement of total non-starch polysacharides by gas-liquid chromatography of constituent sugars as alditol acetates".-Analyst. 109 (1984) 937-942.

42. Berry, C.S.-"Resistant starch: Formation and measurement of starch that survives exhaustive digestion with amylolytic enzymes during the determination of dietary fiber".-J. Cereal Sci. 4 (1986) 301-314. 